\title{
Development of stuffed coalho cheese in the traditional, lactose-free and probiotic-added formulations
}

\author{
Alessandra Cristina Sales Leite ${ }^{1}$ iD Neila Mello dos Santos Cortez ${ }^{2}$ iD \\ Sônia Sousa Melo Cavalcanti de Albuquerque ${ }^{2}$ (D) Neide Kazue Sakugawa Shinohara ${ }^{1}$ (D) \\ Indira Maria Estolano Macedo ${ }^{\text {(D) Samara Alvachian Cardoso Andrade }{ }^{*} \text { iD }}$
}

'Universidade Federal Rural de Pernambuco (UFRPE), 52171-900, Dois Irmãos, Recife, PE, Brasil.

${ }^{2}$ Universidade Federal de Pernambuco (UFPE), Cidade Universitária, 50670-901, Recife, PE, Brasil. E-mail: samaraandrade@uol.com.br. Corresponding author.

ABSTRACT: The probiotic products from the dairy market have been extensively exploited as well as lactose-free derivatives, suitable for lactose intolerant individuals. This research aimed to manufacture stuffed cheese with Brazilian cream cheese and spices in three versions (traditional, lactose-free, and probiotic cheese) and evaluate their quality by physico-chemical and microbiological analyses, Lactic Acid Bacteria (LAB) viability, and acceptance and preference assays. Physico-chemical properties of the formulations were all in accordance with the standards for the fat content of the Ordinance No. 146 for the traditional (54.06\%) and probiotic (45.45\%) full-fat samples and free-lactose (39.28\%) medium-fat sample. Regarding the microbiological safety, all the samples presented to be ready for consumption, and the LAB count were still viable after 42 days of storage in the probiotic formulation at the order of $10^{8} \log C F U / m L$. The lactose-free formulation achieved the highest acceptance rates among the public regarding sensorial qualities with an average grade of 7.27 out of 9 . In the end, the three types of stuffed coalho cheese were successful in total quality control and also the probiotic formulation with the desired viable count after storage and lactose-free formulation with the best acceptance rates by the public.

Key words: stuffed cheese, seasoned Brazilian cream cheese, low lactose content, Lactobacillus casei.

Desenvolvimento de queijo de coalho trufado nas versões tradicional, delactosado e com adição de probiótico

RESUMO: A crescente consciência dos consumidores sobre a relação existente entre saúde e dieta, tem despertado o interesse por alimentos que promovem efeitos benéficos ao ser humano. Desta maneira, o mercado de produtos lácteos com alegações probióticas passou a ser bastante explorado, assim como os delactosados, adequados ao público intolerante a lactose. O objetivo deste estudo foi produzir queijo de coalho trufado com requeijão e especiarias nas versões tradicional, delactosado e com adição de probiótico, sendo realizadas análises físico-química, microbiológicas, viabilidade das bactérias ácido láticas, teste de aceitação e preferência. As características físico-químicas dos queijos produzidos permaneceram dentro dos padrões da legislação brasileira. Os queijos desenvolvidos apresentaram segurança microbiológica para consumo e as bactérias ácido láticas revelaram-se viáveis no produto por um periodo de 42 dias. Considerado mais uma alternativa para o público com intolerância a lactose, o queijo coalho trufado delactosado demonstrou melhor aceitação sensorial em relação as demais versões.

Palavras-chave: queijo recheado, requeijão condimentado, baixa lactose, Lactobacillus casei.

\section{INTRODUCTION}

Coalho cheese is a typical product of the Northeast region of Brazil, where its production process is classically related to the local's tradition and persists to this day in all the producing regions (SOUSA et al., 2014). Widely consumed by people from all social classes and age groups, it plays an important role in the social and economic scenario of the region (BELTRÃO; SANTOS, 2015).

The Brazilian cream cheese, genuinely from Brazil (TORRES et al., 2017), may be presented in several textures, colors, and consistency (CRUZ et al., 2017). Ingredients and technology employed in its manufacturing process are varied (OLIVEIRA et al., 2016) and in most cases, the accessible technologies reflect regional and cultural influences (CRUZ et al., 2017).

Milk and its products are the only nutritious source of lactose, also called milk sugar it is estimated that at least $65 \%$ of the world adult population presents signs of lactose intolerance and the prevalence of this inability to digest lactose differs considerably among races and age groups. The most common symptoms of the condition are flatulence, abdominal cramps, diarrhea, and nausea (ANTUNES et al. 2014). To this public, dairy products low in lactose content arise as an alternative to not excluding these items of their daily diets (BRUMANO et al., 2012). 
The awareness about the relationship between health and diet has aroused concern about food with functional properties that are able to promote long-term positive effects such as metabolic balance to the maintenance of health and well-being (SAAD et al., 2013; LIMA et al., 2014). Among this type of food are the probiotics, living organisms whose function is to improve the balance of the intestinal microbiota when consumed in an adequate amount. They stand out for their advantages and applications, being readily available in dairy products (HILL et al., 2014; KERRY et al. 2018; SANTIAGOLÓPEZ et al., 2018; MOHAN et al., 2020).

Dairy products are an excellent means of transport and reproduction of probiotics and although, they have been on the market for more than a decade now, there are still expectations of the development of new goods involving these microorganisms (KHAN, 2014). The market awaits the launch of foods that feature functional agents and bioactive peptides, which will be part of healthy diets that can prevent or treat degenerative pathologies (DALIRI, OH, LEE, 2017).

The industry is also interested in refining its offers to the public. The use of probiotics in Brazil is relevant in the dairy chain as a potential source of new cultures to the formulation of new products and expansion of the market with emphasis to the main technological advantages associated with its use (COLOMBO et al., 2018; BARROS et al., 2020).

Cheese presents high feasibility to insert probiotics to the gastrointestinal system due to its elevated $\mathrm{pH}$, higher fat content, and solid consistency (ÖZER et al., 2008; MEIRA et al., 2015)

Evaluated the effects of the insertion of Lactobacillus in goat ricotta cheese and reported that the product played a crucial role as a bulk material for the viability of the strains, which were found at concentrations of $6 \log$ CFU/g. Amira et al. (2019) investigated the viability and stability of isolated lactic bacteria in Klila, a Nigerian fermented cheese, under different stress conditions such as the presence of $\mathrm{NaCl}$ at a range of concentrations, $\mathrm{pH}$, and simulated gastrointestinal environment.

The most typical probiotic microorganisms in food manufacturing are from the genus Bifidobacterium and Lactobacillus. The specie Lactobacillus casei (L. casei) has great commercial value due to its versatility in food sorting, providing aroma, flavor, texture and assisting in bioconservation by the acidification process (LIMA et al., 2014; SUMARMONO et al., 2020).

The benefits for human health are wellestablished by many reports. There is evidence that these microorganisms play a role in fighting infections, cardiovascular diseases, obesity, diabetes (VANDENPLAS; HUYS; DAUBE, 2015; ZOUMPOPOULOU et al., 2016), and reducing symptoms of celiac disease (NOROUZBEIGI et al., 2020). A study carried out by Tonnuci et al. (2016) with type 2 diabetes patients, as an example, concluded the daily ingestion of fermented milk added by L. acidophilus LA and B. lactis for six weeks decreased significantly the fasting blood glucose and total cholesterol levels.

The Food and Agriculture Organization (FAO) and the World Health Organization (WHO) determine that the probiotics must be viable and at a great count once they are ingested. However, recent studies have indicated that dead cells (intact or ruptured) are able to display significant impacts on human health. Thereby, new definitions are being added to probiotic terminologies, such as 'paraprobiotics', to refer to inactive probiotic cells, and 'post-biotic' to refer to healthy probiotic metabolites (ZENDEBOODI et al., 2020).

The goal of this research included developing new coalho cheese variants stuffed with Brazilian cream cheese and spices in three versions: traditional, lactosefree, and probiotic formulae. Physico-chemical and microbiological profiles were provided as well as the viability of $\mathrm{LAB}$ and sensorial analyses.

\section{MATERIALS AND METHODS}

\section{Formulation}

Calcium chloride $40 \%(4 \mathrm{~m} / 10 \mathrm{~L})$ (Rich Cream), chymosin (9mL / 10L) (CRH Hansen HALA), $\beta$-galactosidase enzyme $(1 \mathrm{~mL} / \mathrm{L})$ (Globalfood), Direct Vat Set (DVS) L. casei culture (10g/100L) (DELVO PRO LAFTI L26- Globalfood) at a concentration of $10^{12} \mathrm{CFU} / \mathrm{mL}$ and melting salts $(50 \mathrm{~g} / 5 \mathrm{~kg})$ (Rica Nata) were employed according to the manufacturers' specifications. The amounts of iodized sea salt $(1 \%$ in relation to the weight of the dough), flaked onion, granulated garlic, pepperoni pepper, and mix of dehydrated fine herbs (rosemary, thyme, basil, parsley, tarragon, and oregano) were defined based on preliminary sensory tests performed at the Processing of Milk and Derivatives Laboratory (PMDL), Department of Food Engineering (UFPE), Recife, Brazil. The spices accounted for $0.20 \%$ in relation to dough weight.

\section{Lactose removal process}

The delactosation process was performed with $12 \mathrm{~L}$ of the milk in the Laboratory of Food 
Experimentation and Analysis, located in the Department of Nutrition (UFPE), Recife, Brazil. PE. The enzyme $\beta$-galactosidase was added to the milk in a proportion of $10 \mathrm{~g}$ to $100 \mathrm{~L}(0.1 \%)$ according to the manufacturer. The samples went from $7 \pm 2{ }^{\circ} \mathrm{C}$ to $26 \pm 2{ }^{\circ} \mathrm{C}$ in the cryoscopy tests. The monitoring and control of lactose hydrolysis were carried out using a digital electronic cryoscope (MK-540 ITR), according to the methodology provided by the manufacturer. The freezing point of milk was measured at each 30-minute interval and the correlation between cryoscopy and percentage of hydrolysis was used to determine the degree of lactose hydrolysis in the milk sample (Equation 1) (LONGO, 2006).

Crioscopy $=0.00285 \times(\%$ desired hydrolysis rate $)+$ (initial cryoscopy rate)

$\%$ hydrolysis rate $=350.877 \mathrm{x}$ (final cryoscopy rate)

- (initial cryoscopy rate) 0.00285

\section{Preparation of starter cultures}

To prepare the starter culture, L. case dry culture was weighted as recommended by the manufacturer $(10 \mathrm{~g} / 100 \mathrm{~L})$, added to $100 \mathrm{~g}$ of skimmed powder milk previously fluidized $(500 \mathrm{~mL})$ and sterilized in the oven at $105 \pm 1{ }^{\circ} \mathrm{C}$ for 5 minutes. Then, the culture was fractionated in sterile falcon tubes $(10 \mathrm{~mL})$ at a concentration of $10^{12} \mathrm{CFU} / \mathrm{mL}$ and the tubes were frozen. One day before the cheese production, the starter cultures were incubated in an oven at $36{ }^{\circ} \mathrm{C} \pm 1{ }^{\circ} \mathrm{C}$ for activation. The cultures were dispersed in the Brazilian cream cheese and the cheese dough before the packaging step.

\section{Stuffed coalho cheese processing}

The processing of cheese was performed in two steps. The first referred to the production of the stuffing, the spiced cream cheese in traditional, lactosefree, and probiotic formulations (Figure 1). The second step referred to the production of the three formulations of coalho cheese and the insertion of the respective stuffing (Figure 2). Two samples were prepared for each formulation, one to perform physico-chemical, microbiological, and sensory analyses, and another to the viability control. The mass of the samples ranged from 800 to $850 \mathrm{~g}$. Samples were stored in suitable plastic food bags at $5 \pm 2{ }^{\circ} \mathrm{C}$ and relative humidity ranging between $75-80 \%$.

\section{Physico-chemical analyses}

The analyzes of $\mathrm{pH}$, acidity, fatty matter, Fat in the Dry Extract (FDE), protein, and moisture were performed in duplicate at PMDL (UFPE) following the official analytic methods for the quality control of milk and dairy products, according to Ordinance No. 68 from December 12 ${ }^{\text {th }}, 2006$ (BRASIL, 2006) and Official Methods of Analysis (AOAC, 2002).

\section{Microbiological analyses}

The assays were performed in duplicate after $12 \mathrm{~h}$ from the processing at the Microbiology Laboratory in the Technology Department of UFRPE, Recife, Brazil. The methods were following the Ordinance No. 62 from August 26 th, 2003 (BRASIL, 2003), Compact Dry XSA TM AOAC (AOAC - RI Performance Testing Methodology 081001), Compact Dry CF TM AOAC (AOAC - RI Performance Testing Methodology 110402), Compact Dry SL e American Public Health Association APHA (APHA, 2001) guidelines for the analyses of Salmonella spp., thermotolerant coliforms, Coagulase-Positive Staphylococci (CPS), Listeria monocytogenes $35^{\circ} \mathrm{C}$, and molds and yeasts $30^{\circ} \mathrm{C}$.

For the study of growth and viability of the L. casei LAFT-L in the probiotic cheese, the samples were stored at $5 \pm 2{ }^{\circ} \mathrm{C}$ and the counting was performed at weekly intervals $(0,7,14,21,28,35$, and 42 days). Counts were performed in duplicate.

Sample preparation was carried out according to the methodology described by Silva et al. (2017). Samples of $25.00 \pm 1.00 \mathrm{~g}$ of the probiotic cheese were aseptically transferred to flasks containing $225 \mathrm{~mL}$ of peptone salt solution (diluted to $\left.10^{-1}\right)$. The serial dilutions were carried out from this by taking $1 \mathrm{~mL}$ to tubes with $9 \mathrm{~mL}$ of MRS broth until dilution to $10^{-7}$. Dilution aliquots of $1.0 \mathrm{~mL}$ were taken to Petri dishes and poured on MRS agar (20.0 $\mathrm{mL}$ ) followed by homogenization. The Petri dishes were incubated in BOD $\left(\right.$ Tecnal $\left.^{\circledR}\right)$, in anaerobiosis, at $35 \pm 2{ }^{\circ} \mathrm{C}$ for $72 \pm 1 \mathrm{~h}$. Typical colonies (creamy white with irregular edges) were listed and counted with a mechanical colony counter (Phoenix Luferco ${ }^{\circledR}$ ) and the bacterial concentration was expressed in the common logarithm of Colony Forming Units per gram of sample $(\log 10 \mathrm{UFC} / \mathrm{L})$.

\section{Sensory analyses}

The sensory assays took place at the PMDL (UFPE) Firstly, the evaluators sorted the samples according to their preferences from the most preferred sample to the least one and then graded the samples using a 9-point hedonic scale in which 1 meant "I disliked it very much" and 9 meant "I liked it very much" (GARCIA - GÓMEZ et al., 2019).

One hundred candidates among the students, technicians, and other researches at UFPE 




of both sexes and between 18 and 60 years old were recruited by posters. Other requirements for the candidates included liking cheese and not being allergic to milk protein or lactose intolerant. Each taster was instructed on how to fill the sensory questionnaire. Therefore, they received cheese cubic samples with approximately $20 \mathrm{~g}$ each, water and cracker to help clean the palate between tasting different samples. Each sample was coded in $50 \mathrm{~mL}$ plastic cups.

\section{Statistical analysis}

The data were evaluated by analysis of variance (ANOVA) and the Duncan test in order to compare the average results with $95 \%$ of confidence level by STATISTICA 7.0 (Statsoft, Tulsa, EUA).



\section{RESULTS AND DISCUSSION}

\section{Lactose removal process}

The lactose hydrolysis rate was monitored and after about four hours, $90.52 \%$ of lactose content could be converted. Similarly, Back et al. (2013) developed minas frescal cheese formulations from 
pasteurized milk. The milk was previously treated with the $\beta$-galactosidase enzyme at concentrations of $0.3,0.6$, and $0.9 \mathrm{~g} / \mathrm{L}$ and operation times of 12 and 24 hours. The hydrolysis of lactose was obtained at longer operation times with higher doses of the enzyme when compared to the present study. It is believed that the types of enzymes available in the market along with $\mathrm{pH}$, time, and concentration parameters are responsible for this difference (ALMEIDA et al., 2015).

\section{Physico-chemical analyses}

The physico-chemical parameters are exhibited in table 1.

As it can be seen, FDE and humidity results are under what is required by the Brazilian law, Ordinance No 30, from June 26 2001 (BRASIL, 1996; BRASIL, 2001b). There is no significant difference $(\mathrm{P}>0,05)$ among the $\mathrm{pH}$ of formulations $\mathrm{T}$ (6.84), LF (6.87) e P (7.00). They can be classified into "freshly processed" since the $\mathrm{pH}$ values indicate none of them was subjected to ripening or maturation processes, otherwise, the fermentation of the sugar present in the cheese would occur followed by the acidification of the dough (MAGDOUB et al., 2005).

The analyses also revealed no significant difference $(\mathrm{P}>0,05)$ regarding the acidity of formulations T (0.55), LF (0.55) e P (0.40) (Table 1). The probiotic samples were expected to present higher acidity rates than the other samples; although, the results might be explained by the fact that the analyses were run in the initial phase of storage, right after the processing. The relatively low growth rates of $\mathrm{LAB}$ would require more time to increase acidity levels.

Results agreed with other reports in the literature (0.14-0.62) (FERREIRA; FREITAS, 2008).
However, several factors can influence the acidity levels such as the fresh or maturation degree, the coagulation process (acid, enzymatic, or mixed), as well as the addition of microorganisms. As stated by Sumarmono et al. (2020), keeping the cheese at a low $\mathrm{pH}$ is very important to prevent the growth of pathogenic bacteria and most of the deteriorating microorganisms.

According to table 1 , significant differences $(\mathrm{P}<0.05)$ were attained for the cheese $\mathrm{T}(25.00 \%)$, LF $(19.00 \%)$ e P $(20.50 \%)$ regarding the fat content. When compared to other researches in the literature, one can find superior values for coalho cheese such as reported by Fontenele et al. (2017) (28.0\%$32.7 \%)$ and Santos et al. (2011) (24.00\%). This may be related to the initial fat content in the raw milk. The formulation $\mathrm{T}$ and $\mathrm{P}$ exhibited FDE equivalent to 54.06 and $45.45 \%$; respectively, being classified as full-fat types $(45.0 \%-59.9 \%)$, while formulation LF was classified as medium fat $(25.0 \%-44.9 \%)$ according to the Ordinance No. 149 from March $7^{\text {th }}$, 1996 (BRASIL, 1996). Concerning to the protein content, a statistical difference ( $p>0.05)$ could not be observed among T (19.91\%), LF (22.01\%), and P $(21.37 \%)$ samples. This suggested that the coagulation process occurred in a similar way which guarantees the standardization in the manufacturing process. It is worthy to mention that in the coagulation process the casein content plays a major role in the process, but this present study did not apply this methodology. Regarding the moisture levels, the statistical difference could be noticed $(\mathrm{P}<0,05)$ among the samples $\mathrm{T}(53.76 \%)$, LF $(51.63 \%)$ e $\mathrm{P}$ (54.90\%); however, according to the Ordinance No. 146 (BRASIL, 1996), the three formulations can be classified as high-moisture cheese (46.0-54.9\%).

Table 1 - Physico-chemical analyses of the stuffed coalho cheese samples in the traditional, lactose-free, and probiotic formulations.

\begin{tabular}{|c|c|c|c|c|c|c|}
\hline Samples & $\mathrm{pH}$ & Acidity $^{* * *}$ & Fat $(\%)$ & FDE $(\%)$ & Protein $(\%)$ & Moisture (\%) \\
\hline $\mathrm{T}$ & $6.84 \pm 0.13 \mathrm{a}^{* *}$ & $0.55 \pm 0.5 \mathrm{a}^{* *}$ & $25.00 \pm 0.71 \mathrm{a}$ & $54.06 \pm 1.39 \mathrm{a}$ & $19.91 \pm 0.72 \mathrm{a}^{* *}$ & $53.76 \pm 0.09 b$ \\
\hline LF & $6.87 \pm 0.03 \mathrm{a}^{* *}$ & $0.55 \pm 0.5 \mathrm{a}^{* *}$ & $19.00 \pm 0.00 \mathrm{c}$ & $39.28 \pm 1.46 c$ & $22.01 \pm 1.36 \mathrm{a}^{* *}$ & $51.63 \pm 0.05 c$ \\
\hline $\mathrm{P}$ & $7.00 \pm 0.01 \mathrm{a}^{* *}$ & $0.40 \pm 0.5 \mathrm{a}^{* *}$ & $20.5 \pm 0.00 \mathrm{~b}$ & $45.45 \pm 1.29 b$ & $21.37 \pm 0.45 \mathrm{a}^{* *}$ & $54.90 \pm 0.06 \mathrm{a}$ \\
\hline${ }^{*}$ Legislação & NE & NE & NE & $35.00-60.00$ & NE & $36.00-54.90$ \\
\hline
\end{tabular}

*Ordinance $\mathrm{n}^{\circ}$ 30, June 26th, 2001 (BRASIL, 2001a);

** Average values followed by the same letters vertically are not significantly different according to Duncan test ( $\mathrm{p}>0.05$ );

${ }^{* * *}$ Results in grams of lactic acid per every 100 grams of cheese.

$\mathrm{T}$ (traditional formulation), LF (lactose-free formulation), $\mathrm{P}$ (probiotic formulation).

NE (not established). 
Microbiological analyses

The results for the microbiological analyses are displayed in table 2 .

According to the Resolution RDC No. 12 from January $2^{\text {nd }}, 2001$ (BRASIL, 2001a), the Normative Instruction No. 30 from June $26^{\text {th }}, 2001$ (BRASIL, 2001b) and the Ordinance No. 146 from March $7^{\text {th }}, 1996$ (BRASIL, 1996), the three formulations are safe to consume. The pasteurization of milk for cheese manufacturing is known to inhibit the contamination by enteropathogenic agents (BRASIL, 2001; SANTANA et al., 2008; AHMED et al., 2015), as well as hygienic and sanitary care in the production environment can avoid crosscontamination by monitoring probable biological contaminant sources continuously (DETOO et al., 2020; LUIZ, 2008). These findings corroborate the compliance with good manufacturing practices from raw materials to cheese processing and current health standards (BRASIL, 2004).

Molds and Yeasts, deteriorating microorganisms, were detected at average concentrations of $2.10^{2}, 10^{2}$, and $<10 \mathrm{CFU} / \mathrm{g}$ in $\mathrm{T}$, $\mathrm{LF}$, and $\mathrm{P}$ samples, respectively. This contamination is possibly related to the spices once their microbiological quality was not monitored in this study (QUEIROGA et al., 2009). According to Oliveira and co-authors (2017), spices containing high loads of conidial fungi are likely to promote microbial contamination when added in the preparation processes, increasing the risk of food spoilage. Since some of these genera are psychrotrophic and able to develop in refrigerated environments, the low temperature of storage did not manage to inhibit the growth of these species (EHSANNIA; SANJABI, 2016).
The $\mathrm{P}$ cheese samples exhibited a lower count of mold and yeast when compared to $\mathrm{T}$ and LF samples (Table 2) which can be explained by the antimicrobial activity that probiotic bacteria displays within the bulk in which they are incorporated (MARIANELLI; CIFANI; PASQUALI, 2010; COSTA et al., 2012; PENG et al., 2015).

Despite the analyses were carried out with the fresh cheese samples, results were similar to the ones displayed by Ehsannia and Sanjabi (2016), who added the probiotic microorganism $B$. coagulans in processes cheese samples and achieved a considerable reduction in the total count of molds and yeasts in 60 days of refrigerated storage.

The LAB counts in the coalho stuffed cheese samples are shown in table 3 .

The $\mathrm{T}$ and $\mathrm{LF}$ samples presented initial LAB counts at 5.09 and $5.97 \mathrm{CFU} / \mathrm{g}$, respectively, and decreased to 2.67 and $2.43 \mathrm{CFU} / \mathrm{g}(\mathrm{P}<0.05)$ after 42 days of storage. These values are characteristic of the natural microbiota since milk was used as the raw material in the manufacturing process (ORTOLANI et al., 2010). They are present in the material even after the pasteurization treatment (HOORDE et al., 2010).

The $\mathrm{P}$ samples revealed lower LAB counts in all the storage periods with a significant difference $(\mathrm{P}<0.05)$ than the other results. This may be explained by the addition of L. casei $\left(10^{12} \mathrm{CFU} /\right.$ $\mathrm{mL}$ ) during the manufacturing process. The viability of the probiotic culture from the first weeks to the expiration date was kept at the magnitude of $10^{8}$ $\mathrm{CFU} / \mathrm{g}$ due to some reasons such as solid bulk, high levels of fat content, anaerobic conditions of storage, and buffering capacity of the medium confirming the

Table 2 - Microbiological analyses of the stuffed coalho cheese samples in the traditional, lactose-free, and probiotic formulations.

\begin{tabular}{|c|c|c|c|c|c|}
\hline Samples & $\begin{array}{c}\text { Thermotolerant } \\
\text { coliforms }\end{array}$ & $\begin{array}{l}\text { Coagulase-positive } \\
\text { Staphylococcus }\end{array}$ & Salmonella sp. & $\begin{array}{c}\text { Listeria } \\
\text { monocytogenes }\end{array}$ & Molds and Yeasts \\
\hline $\mathrm{T}$ & $<1.0$ & $<1.0$ & Absence & Absence & $2 \times 10^{2}$ \\
\hline $\mathrm{LF}$ & $<1.0$ & $<1.0$ & Absence & Absence & $10^{2}$ \\
\hline $\mathrm{P}$ & $<1.0$ & $<1.0$ & Absence & Absence & $<10$ \\
\hline $\mathrm{Law}^{*}$ & $5 \times 10^{3}$ & $10^{3}$ & Absence & Absence & $\mathrm{NE}$ \\
\hline Law $^{* *}$ & $5 \times 10^{3}$ & $10^{3}$ & Absence & Absence & $\mathrm{NE}$ \\
\hline \multicolumn{6}{|c|}{ * Resolution RDC No. 12 from January 2nd, 2001 (BRASIL, 2001a) } \\
\hline \multicolumn{6}{|c|}{ ** Ordinance $\mathrm{n}^{\circ}$ 30, June 26th, 2001 (BRASIL, 2001b) / Ordinance No. 146, March 7th, 1996 (BRASIL, 1996) } \\
\hline
\end{tabular}

Results in colony-forming units per gram (CFU/g).

$\mathrm{T}$ (traditional formulation), LF (lactose-free formulation), $\mathrm{P}$ (probiotic formulation).

NE (not established) 
Table 3 - LAB count for the samples of stuffed coalho cheese stored at $5 \pm 2{ }^{\circ} \mathrm{C}$ for 42 days.

\begin{tabular}{|c|c|c|c|c|c|c|c|}
\hline & Initial & $1 \mathrm{st}$ & 2nd & $3 \mathrm{rd}$ & $4 \mathrm{rd}$ & $5 \mathrm{rd}$ & 6rd \\
\hline $\mathrm{T}$ & $5.09 \pm 0.01 \mathrm{Ca}$ & $4.52 \pm 0.05 \mathrm{Cb}$ & $4.04 \pm 0.06 \mathrm{Cc}$ & $3.07 \pm 0.01 \mathrm{Cd}^{*}$ & $3.07 \pm 0.01 \mathrm{Cd}^{*}$ & $2.51 \pm 0.01 \mathrm{Cf}$ & $2.67 \pm 0.01 \mathrm{Be}$ \\
\hline LF & $5.97 \pm 0.01 \mathrm{Ba}$ & $4.86 \pm 0.01 \mathrm{Bb}$ & $4.43 \pm 0.02 \mathrm{Bd}$ & $4.80 \pm 0.01 \mathrm{Bc}$ & $3.85 \pm 0.03 \mathrm{Be}$ & $3.72 \pm 0.03 \mathrm{Bf}$ & $2.43 \pm 0.03 \mathrm{Cg}$ \\
\hline$P$ & $8.96 \pm 0.01 \mathrm{Aa}$ & $8.93 \pm 0.01 \mathrm{Ab}^{*}$ & $8.91 \pm 0.01 \mathrm{Ab}^{*}$ & $8.50 \pm 0.01 \mathrm{Ac}$ & $7.86 \pm 0.01 \mathrm{Ae}$ & $7.81 \pm 0.01 \mathrm{Af}$ & $7.91 \pm 0.01 \mathrm{Ad}$ \\
\hline
\end{tabular}

Results in $\log (\mathrm{CFU} / \mathrm{g})$.

$\mathrm{T}$ (traditional formulation), LF (lactose-free formulation), $\mathrm{P}$ (probiotic formulation).

Equal letters $\mathrm{ABC}$, vertically, are not significantly different according to the Duncan test $(\mathrm{P}>0.05)$;

Equal letters abc, horizontally, are not significantly different according to the Duncan test $(\mathrm{P}>0.05)$;

functional properties of the product (COMAN et al., 2012; GREGOR, 2015; CRUZ et al., 2017).

According to the Brazilian legislation, the count of probiotics must reach a minimum of 8 to $9 \log \mathrm{CFU} / \mathrm{g}$ for the daily recommendation for consumption. Furthermore, inferior values are to be accepted by proving the safety and health benefits promoted by probiotics in food (BRASIL, 2018).

For products added by probiotic cultures, the functional value must be communicated through the approved functional or health claim for the strain. Proof of benefit for probiotics requires demonstration of survival to human digestive tract conditions and evidence of the effect on humans obtained in studies within the same strain. The evaluation must be carried out with a representative group of the population of interest, take into consideration the minimum suggested quantity to obtain the benefits, evaluate relevant outcomes for the claimed benefit, and minimize bias and uncertainty factors regarding its safe consumption (BRASIL, 2018).

According to table 3 , the probiotic samples presented LAB counts over $8 \log \mathrm{CFU} / \mathrm{g}$ up to 21 days of storage, emerging as a potential probiotic product for the market (BRASIL, 2008). After this period, the counts were superior to $7 \log \mathrm{CFU} / \mathrm{g}$. Despite the reduction in cell viability, it remained at the levels recommended by FAO/WHO (2003) and the food industry, which, in general, indicates a minimum of 6 $\log$ UFC/g to produce possible positive effects to the consumer. Some studies also reported that inactive cells are associated with positive responses to the human organisms (KARIMI; MORTAZAVIAN; CRUZ, 2011; SIDIRA et al., 2017).

The $\mathrm{P}$ cheese sample achieved counts from 8.69 to $7.91 \log \mathrm{CFU} / \mathrm{g}$ for 42 days of analyses. Plessas et al. (2012) and Vandenplas et al. (2015) stated that if the viable probiotic count is above $6 \log \mathrm{CFU} / \mathrm{g}$ after 7 days of storage, the product can be considered satisfactory to provide beneficial health effects (TRIPATHI \& GIRI, 2014). The substantial count and viability may be related to the influence of the raw materials (cheese bulk and cream cheese) in the probiotic and acid content during the storage period (CUNHA et al., 2009). Bulk is known to protect the microorganisms along the path to the intestines, such as mild buffer environment, the high moisture levels in fresh cheese formulations, high-fat content, and solid medium. This transport is more efficient than in fermented milk beverages for example (HANSEN, 2011). It is also worth mentioning the production of national cheese products, such as the coalho cheese and Brazilian cream cheese.

Table 4 shows the results for the count of mesophilic microorganisms in $\mathrm{T}$, LF, and $\mathrm{P}$ formulations, which decreased significantly different $(\mathrm{P}<0.05)$ over 42 days of storage.

The initial counts of mesophilic microorganisms in LF and P samples were 10.76 and $12.44 \log \mathrm{CFU} / \mathrm{g}$, respectively, both higher than in the traditional samples (8.65 log CFU/g). Similarly, significant differences could be observed in the final global count, $7.73 \log \mathrm{CFU} / \mathrm{g}$ for LF samples, 5.93 $\log \mathrm{CFU} / \mathrm{g}$ for $\mathrm{P}$ samples, and $5.05 \mathrm{log} \mathrm{CFU} / \mathrm{g}$ for $\mathrm{T}$ samples. The care for cleaning and sanitizing the manufacturing equipment, as well as all the processing were identical for the three cheese formulations produced; however, extra handling procedures may have caused an increase in contamination of the LF and P samples (KOUSTA et al., 2010).

According to the results, the content of mesophilic bacteria decreased along the storage period. This may have been caused by the presence of the natural microbiota of the products, which 
Table 4 - Mesophilic microorganisms counts in stuffed coalho cheese stored at $5 \pm 2{ }^{\circ} \mathrm{C}$ for 42 days.

\begin{tabular}{|c|c|c|c|c|c|c|c|}
\hline & Initial & $1 \mathrm{st}$ & 2 nd & $3 \mathrm{rd}$ & $4 \mathrm{rd}$ & $5 \mathrm{rd}$ & 6rd \\
\hline $\mathrm{T}$ & $8.65 \pm 0.01 \mathrm{Ca}^{*}$ & $8.60 \pm 0.01 \mathrm{Ca}^{*}$ & $7.54 \pm 0.01 \mathrm{Cb}$ & $7.05 \pm 0.07 \mathrm{Bc}^{* *}$ & $6.79 \pm 0.01 \mathrm{Bd}$ & $6.50 \pm 0.01 \mathrm{Be}$ & $5.05 \pm 0.07 \mathrm{Cf}$ \\
\hline $\mathrm{LF}$ & $10.76 \pm 0.01 \mathrm{Ba}$ & $10.56 \pm 0.02 \mathrm{Bb}$ & $8.81 \pm 0.01 \mathrm{Bc}$ & $8.26 \pm 0.01 \mathrm{Ad}$ & $7.95 \pm 0.01 \mathrm{Ae}$ & $7.85 \pm 0.03 \mathrm{Af}$ & $7.73 \pm 0.02 \mathrm{Ag}$ \\
\hline $\mathrm{P}$ & $12.44 \pm 0.02 \mathrm{Aa}$ & $11.05 \pm 0.02 \mathrm{Ab}$ & $9.85 \pm 0.06 \mathrm{Ac}$ & $7.09 \pm 0.03 \mathrm{Bd}^{* *}$ & $6.68 \pm 0.03 \mathrm{Ce}$ & $6.07 \pm 0.04 \mathrm{Cf}$ & $5.93 \pm 0.04 \mathrm{Bg}$ \\
\hline
\end{tabular}

Results in $\log (\mathrm{CFU} / \mathrm{g})$.

$\mathrm{T}$ (traditional formulation), LF (lactose-free formulation), $\mathrm{P}$ (probiotic formulation).

*Equal letters abc, horizontally, are not significantly different according to the Duncan test $(\mathrm{P}>0.05)$;

${ }^{* *}$ Equal letters $\mathrm{ABC}$, vertically, are not significantly different according to the Duncan test $(\mathrm{P}>0.05)$;

inhibit the growth of pathogens. The mechanisms of inhibition include oxygen competition, binding sites competition, and the production of bacteriocins and antimicrobial proteins (MARTINIS et al., 2003; CARVALHO et al., 2015; ORTOLANI et al., 2010). These results are corroborated with the highest reductions in the probiotic samples after 42 days, which highlights the bactericidal properties of $L$. casei added to the process. The addition of dairy probiotic cultures can contribute to maintaining the microbiological quality of the cheese during the storage periods (COSTA et al., 2012).

\section{Sensory analysis}

The acceptance evaluation for the product global quality revealed so significant difference
$(\mathrm{P}>0.05)$ between LF and $\mathrm{P}$ cheese samples, but both exhibited statically different acceptance rates $(\mathrm{P}<0.05)$ when compared to the traditional formulation. The greatest acceptance rate was achieved by the LF formulation (Figure 3), which can be reasoned by the addition of $\beta$-galactosidase enzyme in the removal of the lactose process, making the milk taste sweeter due to the higher content of glucose (LONGO; WASZCZYNSKYJ, 2006). Regarding the preference assays, LF samples were demonstrated to be the chosen ones by the public with a significant difference $(\mathrm{P}<0,05)$ when compared to $\mathrm{T}$ and $\mathrm{P}$ samples (Table 5). This result is in accordance with the acceptance rates evaluation (Figure 3).

NICOLETTI et. al. (2017) obtained similar results in the sensory analysis of cottage cheese with

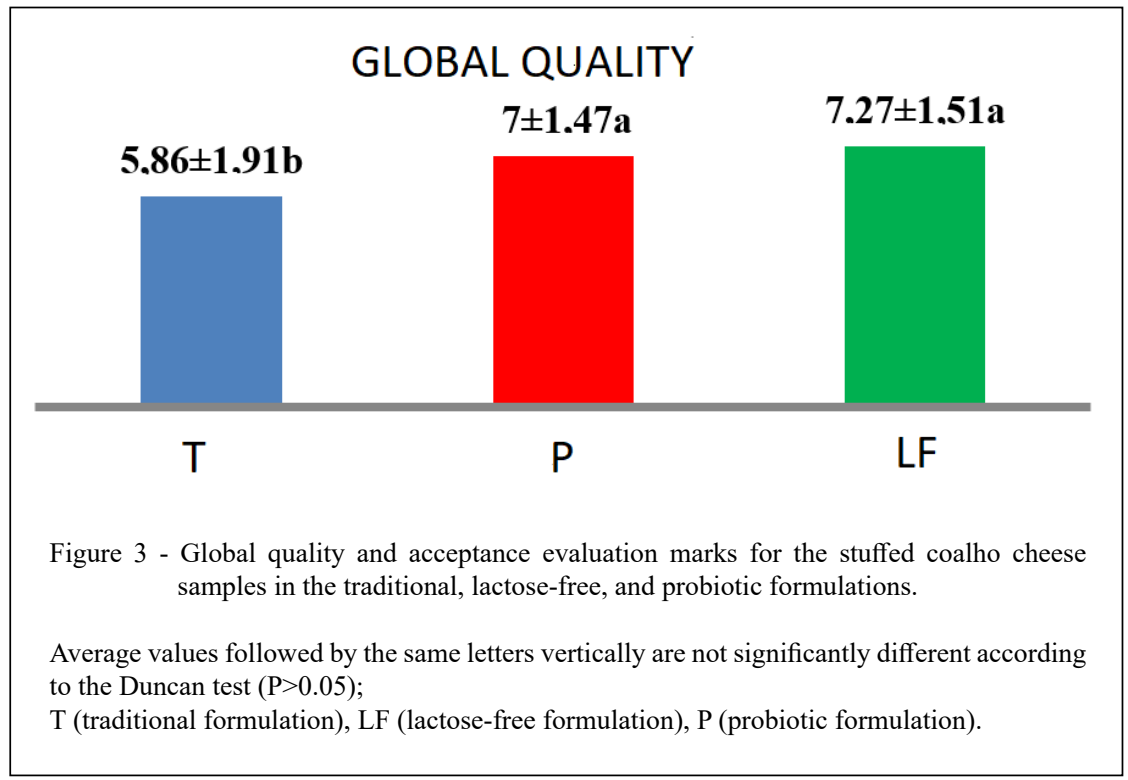

Ciência Rural, v.51, n.5, 2021. 
Table 5 - Preference results of the stuffed coalho cheese samples in the traditional, lactose-free, and probiotic formulations.

\begin{tabular}{lcc}
\hline & & \\
& & \\
\hline$T$ & LF & \\
\hline $248 \mathrm{a}$ & $168 \mathrm{~b}$ & $\mathrm{P}$ \\
\hline
\end{tabular}

*Equal letters are not significantly different according to the Friedman test $(\mathrm{p}>0.01)$.

$\mathrm{T}$ (traditional formulation), LF (lactose-free formulation), $\mathrm{P}$ (probiotic formulation).

42 tasters. The lactose-free formulation of the product obtained $61.9 \%$ of the score in the two top grades.

\section{CONCLUSION}

The development of traditional, lactosefree, and probiotic-added stuffed coalho cheese with Brazilian cream cheese and spices was successful since physico-chemical and microbiological standards were met as established by the Law. All the products were concluded to be safe for consumption and the probiotic formulation kept the viable cell counts in compliance with the Brazilian legislation international standards. Thus, that is enough to characterize it as a product with potential probiotic activity. The lactosefree coalho cheese presented the acceptance rate besides being the alternative for lactose-intolerant consumers. Future investigations on the physicochemical and microbiological properties and global product acceptance throughout the storage period of the products will be important in aiding to meet the demands of the functional product market.

\section{ACKNOWLEDGEMENTS}

This study was financed in part by the Coordenação de Aperfeiçoamento de Pessoal de Nível Superior - Brasil (CAPES) Social Demand Program. IES - UFRPE Course - 25003011021PO Food Science and Technology, Modality - Master.

\section{APPROVAL OF THE BIOETHICS AND BIOSAFETY COMMITTEE}

The study was approved by the Permanent Research Ethics Committee of the University of Pernambuco (Order No. 2,432,022).

\section{DECLARATION OF CONFLICTS OF INTERESTS}

The authors would like to declare no conflicts of interest regarding the research, authorship, and publication of this work.

\section{AUTHORS' CONTRIBUTIONS}

The authors contributed equally to the manuscript.

\section{REFERENCES}

ALMEIDA, K. N. de et al. Enzymatic hydrolysis of whey permeate lactose. Revista do Instituto de Laticínios Cândido Tostes, v.70, n.2, p.55-63, 2015. Available from: <https://www.revistadoilct. com.br/rilct/article/view/363>. Accessed: May, 02, 2020. doi: 10.14295/2238-6416.v70i2.363.

AMIRA, S. et al. Effect of different food stress conditions on the viability of encapsulated Lactobacillus plantarum and Lactobacillus casei isolated from klila (an algerian traditional fermented cheese). Journal of Microbiology, Biotechnology and Food Sciences, v.9, n.1, p.38-43, 2019. Available from: <https:// www.researchgate.net/publication/333486615>. Accessed: May, 02, 2020. doi: 10.15414/jmbfs.2019.9.1.38-43.

ANTUNES, A. E. C. et al. Development and shelf-life determination of pasteurized, microfiltered, lactose hydrolyzed skim milk. Journal of Dairy Science, v.97, n.9, p.5337-5344, 2014. Available from: <https://www.journalofdairyscience.org/ article/S0022-0302(14)00493-7/pdf >. Accessed: Jan. 12, 2018. doi: $10.3168 /$ jds.2014-8020.

BACK, D. et al. Probiotic viability of minas fresh cheeses with reduced lactose content. Revista do Instituto de Laticínios Cândido Tostes, v.68, n.390, p.27-35, 2013. Available from: $<$ https://www.researchgate.net/publication/269942751>. Accessed: May, 02, 2020. doi: 10.5935/2238-6416.20130005.

BARROS, C.P. et al. Paraprobiotics and postbiotics: concepts and potential applications in dairy products. Current Opinion in Food Science, v.32, p.1-8, 2020. Available from: https://www. sciencedirect.com/science/article/abs/pii/S2214799319301328. Accessed: Jun. 02, 2020. doi: 10.1016/j.cofs.2019.12.003.

BRASIL. Ministério da Agricultura Pecuária e Abastecimento. Instrução Normativa $n^{0}$ 68, de 12 de dezembro de 2006. Aprova os métodos analíticos oficiais físico-químicos, para controle de leite e produtos lácteos. Diário Oficial da República Federativa do Brasil, Brasília, DF, 14 dez. 2006.

BRASIL. Ministério da Saúde. Agência Nacional de Vigilância Sanitária. Resolução RDC $\mathbf{n}^{\circ} \mathbf{2 1 6}$, de 15 de setembro de 2004. Dispõe sobre Regulamento Técnico de Boas Práticas para Serviços de Alimentação. Diário Oficial da União, Poder Executivo, 16 set. 2004.

BRASIL. Ministério da Agricultura Pecuária e Abastecimento. Instrução Normativa $\mathbf{n}^{\circ}$ 62, de 26 de agosto de 2003. Oficializar os métodos analíticos oficiais para análises microbiológicas para controle de produtos de origem animal e água. Diário Oficial da República Federativa do Brasil, Brasília, DF, 18 set. 2003.

BRASIL. Ministério da Saúde. Agência Nacional de Vigilância Sanitária. Resolução RDC $\mathbf{n}^{\mathbf{0}} \mathbf{1 2}$, de 02 de janeiro de 2001. Aprova o Regulamento Técnico sobre padrões microbiológicos para alimentos. Diário Oficial da União, Poder Executivo, 10 jan. 2001. a.

BRASIL. Ministério da Agricultura, Pecuária e Abastecimento. Instrução normativa $n^{0}$ 30, de 26 de junho de 2001. Aprova os 
Regulamentos Técnicos de Identidade e Qualidade de Manteiga da Terra ou Manteiga de Garrafa; Queijo de Coalho e Queijo de Manteiga. Diário Oficial da República Federativa do Brasil, Brasília, DF, 16 jul. 2001. b.

BRASIL. Ministério da Agricultura, Pecuária e Abastecimento. Portaria $\mathrm{n}^{\circ} 146$ de 07 de março de 1996. Aprova os regulamentos técnicos de identidade e qualidade dos produtos lácteos. Diário Oficial da República Federativa do Brasil, Brasília, DF, 11 mar. 1996.

BRASIL. Ministério da Saúde. Agência Nacional de Vigilância Sanitária. Alimentos com alegações de propriedades funcionais e ou de saúde, novos alimentos/ingredientes, substâncias bioativas e probióticos. 2008. Available from: $<\mathrm{http} / / \mathrm{www}$. anvisa.gov.br/alimentos/comissoes/tecno_lista_alega.htm>. Accessed: Apr. 03, 2017.

BRASIL. Ministério da Saúde. Agência Nacional de Vigilância Sanitária. Resolução RDC n⿳0 241 , de 26 de julho de 2018. Dispõe sobre os requisitos para comprovação da segurança e dos benefícios à saúde dos probióticos para uso em alimentos. Diário Oficial da União, Poder Executivo, 27 jul. 2018.

CARVALHO, R. J. etal. Comparative inhibitory effects of Thymus vulgaris L. essential oil against Staphylococcus aureus, Listeria monocytogenes and mesophilic starter co-culture in cheese-mimicking models. Food Microbiology, v.52, p.59-65, 2015. Available from: <https://www. sciencedirect.com/science/article/pii/S0740002015001252>. Accessed: Jul. 02, 2020. doi: 10.1016/j.fm.2015.07.003.

COLOMBO, M.;et al.,. (2018). The potential use of probiotic and beneficial bacteria in the Brazilian dairy industry. Journal of Dairy Research, v.85, p.487-496, 2018. Available from: $<$ https://www.cambridge.org/core/services/aop-cambridgecore/content/view/90AE9D7B70989C871C498D9F7A409214 S0022029918000845a.pdf/potential_use_of_probiotic_and_ beneficial_bacteria_in_the_brazilian_dairy_industry.pdf $>$. Accessed: Jun. 02, 2020. doi: 10.1017/S0022029918000845.

COMAN, M. M. et al. Functional foods as carriers for SYNBIO ${ }^{\circledR}$, a probiotic bacteria combination. International Journal of Food Microbiology, v.157, n.3, p.346-352, 2012. Available from: $<$ https://pubmed.ncbi.nlm.nih.gov/22727086/>.: Abr. 02, 2020. doi: 10.1016/j.ijfoodmicro.2012.06.003.

COSTA, G. N. et al. Antimicrobial activity of Lactobacillus and Bifidobacterium strains against pathogenic microorganisms "in vitro". Semina: Ciências Agrárias, v.33, n.5, p.18391846, 2012. Available from: <https://www.researchgate. net/publication/269925654>. Accessed: Sep. 02, 2020. doi: 10.5433/1679-0359.2012v33n5p1839.

CRUZ, A. G. et al. Processamento de produtos lácteos: queijos, leites fermentados, bebidas lácteas, sorvetes, manteiga, creme de leite, doce de leite, soro em pó e lácteos funcionais. Rio de Janeiro: Elsevier, 2017. Ed. 1, v.3, 360p.

CUNHA, T. M. et al. The influence of whey and probiotic bacteria on the properties of fermented lactic beverages. Brazilian Journal of Food Technology, v.12, n.1, p.23-33, 2009. Available from: <https://www.researchgate.net/publication/250389497>. Accessed: Jun. 02, 2020. doi: 10.4260/BJFT20092008.

DALIRI, E. B-M et al. Bioactive peptides. Foods, v.6, n.5 p.1-22, 2017. Available from: $<$ https://www.mdpi.com/2304-8158/6/5/32>. Accessed: Aug. 02, 2020. doi: 10.3390/foods6050032.
DETOO, K. Hygienic conditions and quality of dishes cooked and sold by women traders in the town of Korhogo. Journal of Advances in Microbiology, v.20, n.7, p.1-10, 2020. Available from: $<$ https://www.mdpi.com/2304-8158/6/5/32>. Accessed: Sep. 02, 2020. doi: 10.3390/foods6050032.

EHSANNIA, S.; SANJABI, M. R. Physicochemical, microbiological and spoilage analysis of probiotic processed cheese analogues with reduced emulsifying salts during refrigerated storage. Journal of Food Science and Technology, v.53, n.2, p.996-1003, 2016. Available from: <https://link.springer. com/article/10.1007/s13197-015-2159-7>. Accessed: Jun. 02, 2020. doi: 10.1007/s13197-015-2159-7.

FERREIRA, W. L.; FREITAS FILHO, J. R. de. Evaluation of physical-chemical quality of coalho cheese marketed in the municipality of Barreiros-PE. Revista Brasileira de Tecnologia Agroindustrial, v.2, n.1, p.1-6, 2008. Available from: <https:// link.springer.com/article/10.1007/s13197-015-2159-7>. Accessed: Apr. 02, 2020. doi: 10.1007/s13197-015-2159-7.

FONTENELE, M. A. et al. Peptide profile of coalho cheese: a contribution for protected designation of origin (PDO). Food Chemistry, v.219, p.382-390, 2017. Available from: <https:// www.researchgate.net/publication/308872417>. Accessed: Mar. 02, 2020 doi: 10.1016/j.foodchem.2016.09.171.

GARCIA-GÓMEZ, B. et al. Sensory quality and consumer acceptance of skim yoghurt produced with transglutaminase at pilot plant scale. International Journal of Dairy Techonology, v.72, n.3, p. 388-394, 2019. Available from: $<$ https://onlinelibrary. wiley.com/doi/abs/10.1111/1471-0307.12595>. Accessed: Feb. 02, 2020. doi:10.1111/1471-0307.12595.

GREGOR, R. The growth potential for dairy probiotics. International Dairy Journal, v.49, p.16-22, 2015. Available from: $\quad<\mathrm{https}: / /$ www.sciencedirect.com/science/article/pii/ S0958694615000916>. Accessed: Jan. 02, 2020 doi: 10.1016/j. idairyj.2015.04.004.

HANSEN,C.Culturasprobióticasemprodutoslácteos. Revista Food Ingredients Brasil, n.17, 2011. Available from: <https://revista-fi. com.br/upload_arquivos/201606/2016060697143001467219585. pdf $>$. Accessed: May, 02, 2020.

HILL, C. et al. Expert consensus document, the international scientific association for probiotics and prebiotics consensus statement on the scope and appropriate use of the term probiotic. Nature Reviews Gastroenterology \& Hepatology, v.11, p.506-514, 2014. Available from: $<$ https://www.nature.com/articles/nrgastro.2017.75>. Accessed: Jun. 02, 2020. doi:10.1038/nrgastro.2017.75.

KARIMI, R. et al. Viability of probiotic microorganisms in cheese during production and storage: a review. Dairy Science and Technology, v.91, n.3, p.283-308, 2011. Available from: $<$ https:// www.researchgate.net/publication/225866148>. Accessed: Apr. 02, 2020. doi: 10.1007/s13594-011-0005-x.

KERRY, R.G. et al.. Benefaction of probiotics for human health a review. Journal of Food and Drug Analysis, v.26, p.927-939, 2018. Available from: <https://www.sciencedirect.com/science/ article/pii/S1021949818300309>. Accessed: May, 02, 2020. doi: 10.1016/j.jfda.2018.01.002.

KOUSTA, M. et al. Prevalence and sources of cheese contamination with pathogens at farm and processing levels. Food Control, v.21, 
n.6, p.805-815, 2010. Available from: $<$ https://www.researchgate. net/publication/222077254>. Accessed: Jun. 02, 2020. doi: 10.1016/j.foodcont.2009.11.015.

KHAN, S. U. Probiotics in dairy foods: a review. Nutrition \& Food Science, v.44, p.71-88, 2014. Available from: $<$ https://www. emerald.com/insight/content/doi/10.1108/NFS-04-2013-0051/full/ html>. Accessed: Jun. 02, 2020. doi: 10.1108/NFS-04-2013-0051.

LIMA, J. R. et al. Incorporation of microencapsulated Lactobacillus casei in coalho cheese. Revista Ciência \& Saúde, v.7, n.1, p.2734, 2014. Available from: $<$ https://revistaseletronicas.pucrs.br/ojs/ index.php/faenfi/article/view/15639>. Accessed: Jul. 02, 2020. doi: 10.15448/1983-652X.2014.1.15639.

MAGDOUB, M. N. I. et al. Effect of different starter cultures on composition and microbiological quality of ain shams cheese. Egyptian Journal of Applied Science, v.10, p.132-141, 2005.

MARIANELLI, C. et al. Evaluation of antimicrobial activity of probiotic bacteria against Salmonella enterica subsp. enterica serovar Typhimurium 1344 in a common medium under different environmental conditions. Research in Microbiology, v.161, n.8, p.673-680, 2010. Available from: <https://pubmed.ncbi.nlm. nih.gov/20600855/>. Accessed: Sep. 02, 2020. doi: 10.1016/j. resmic.2010.06.007.

MARTINIS, E. C. P. de et al. Bioconservação de alimentos: aplicação de bactérias lácticas e suas bacteriocinas para a garantia da segurança microbiológica de alimentos. Biotecnologia ciência e Desenvolvimento, v.29, p.114-119, 2003.

MEIRA, Q. G. S. et al. Effects of added Lactobacillus acidophilus and Bifidobacterium lactis probiotics on the quality characteristics of goat ricotta and their survival under simulated gastrointestinal conditions. Food Research International, v.76, p.828-838, 2015. Available from: <https://www.sciencedirect.com/science/ article/pii/S096399691530137X>. Accessed: Feb. 02, 2020. doi:10.1016/j.foodres.2015.08.002.

MOHAN, A. et al. Sensory microbiological and physicochemical characterisation of functional monuka honey yogurts containing probiotic Lactobacillus reuteri DPC16. Foods, v.9, n.106, 2-17, 2020. Available from: <https://www.ncbi.nlm.nih.gov/pmc/ articles/PMC7023061/>. Accessed: Sep. 02, 2020. doi: 10.3390/ foods 9010106 .

NICOLETTI, G. et al. Development of cottage cheese lactose free with fiber addition and reduction of sodium and fat. Revista Instituto de Laticínios Candido Tostes, Juiz de Fora, v.71, n.4, p.186-196, 2017. Available from: <https://www.revistadoilct. com.br/rilct/article/view/461>. Accessed: Jun. 02, 2020. doi: 10.14295/2238-6416.v71i4.461.

NOROUZBEIGI, S. et al. Celiac therapy by administration of probiotics in food products: a review. Current Opinion in Food Science, v.32, p.58-66, 2020. Available from: <https://pubag. nal.usda.gov/catalog/6824645>. Accessed: Sep. 02, 2020. doi: 10.1016/j.cofs.2020.01.005.

OLIVEIRA, R. B. A. et al. Processed cheese contamination by spore-forming bacteria: a review of sources, routes, fate during processing and control. Trends in Food Science \& Technology, v.57, p.11-19, 2016. Available from: <https://www.researchgate. net/publication/308387920>. Accessed: Jan. 02, 2020. doi: 10.1016/j.tifs.2016.09.008
OLIVEIRA, J. O. et al. Microbiological quality of dehydrated spices commercialized in street markets of Cuiaba, Mato Grosso. Journal Health NPEPS, v.2, n.2, p.365-379, 2017. Available from: <http:// docs.bvsalud.org/biblioref/2020/03/1053086/2572-8868-4-pb. pdf $>$. Accessed: May, 02, 2020.

ORTOLANI, M. B. T. et al. Microbiological quality and safety of raw milk and soft cheese and detection of autochthonous lactic acid bacteria with antagonistic activity against Listeria monocytogenes, Salmonella spp., and Staphylococcus aureus. Pathogens and Disease, v.7, n.2, p.175-176, 2010. Available from: $<$ https://www. liebertpub.com/doi/10.1089/fpd.2009.0390>. Accessed: Feb. 02, 2020. doi: $10.1089 /$ fpd.2009.0390.

ÖZER, B. et al. Effect of microencapsulation on viability of Lactobacillus acidophilus LA-5 and Bifidobacterium bifidum BB12 during kasar cheese ripening. International Journal of Dairy Technology, v.61, n.3, p.237-244, 2008. Available from: <https:// onlinelibrary.wiley.com/doi/abs/10.1111/j.1471-0307.2008.00408. $\mathrm{x}>$. Accessed: May, 02, 2020 . doi: 10.1111/j.14710307.2008.00408.x.

PENG, M. et al. Metabolites produced during the growth of probiotics in cocoa supplementation and the limited role of cocoa in host-enteric bacterial pathogen interactions. Food Control, v.53, p.124-133, 2015. Available from: $<$ https://pubag.nal.usda. gov/catalog/5431003>. Accessed: Jul. 02, 2020. doi: 10.1016/j. foodcont.2015.01.014.

PLESSAS, S. et al. Potential effects of probiotics in cheese and yogurt production: a review. Engineering in Life Sciences, v.12, n.4, p.433-440, 2012. Available from: <https://onlinelibrary.wiley. com/doi/full/10.1002/elsc.201100122>. Accessed: May, 02, 2020. doi: 10.1002/elsc.201100122.

QUEIROGA, R. de C. R. do E. et al. Processing and physicochemical, microbiological and sensorial characterization of spicy "tipo minas frescal" goat milk cheese. Revista Ciência Agronômica, v.40, n.3, p.363-372, 2009. Available from: <https://www.researchgate.net/ publication/237028729>. Accessed: Jan. 02, 2020.

$\mathrm{SAAD}, \mathrm{N}$. et al. An overview of the last advances in probiotic and prebiotic field. LWT e Food Science and Technology, v.50, n.1, p.1-16, 2013. Available from: <https://www.researchgate.net/ publication/256804566>. Accessed: Aug. 02, 2020. doi: 10.1016/j. lwt.2012.05.014.

SANTANA, R. F. et al. Microbiological quality of coalho cheese marketed in Aracaju, SE. Arquivo Brasileiro de Medicina Veterinária e Zootecnia, v.60, n.6, p.15171522, 2008. Available from: https://www.researchgate.net/ publication/262761509. Accessed: Aug. 02, 2020. doi: 10.1590/ S0102-09352008000600031.

SANTOS, B. M. et al. Quality and acceptance of goat milk coalho cheese with inclusion of cow milk. Revista do Instituto Adolfo Lutz, v.70, n.3, p.302-310, 2011. Available from: <http://www. ial.sp.gov.br/resources/insituto-adolfo-lutz/publicacoes/rial/10/ rial70_3_completa/1378.pdf $>$. Accessed: Jan. 02, 2020.

SANTIAGO-LÓPEZ, L., Invited review: bioactive compounds produced during cheese ripening and health effects associated with aged cheese consumption. Journal of dairy science, v.10, n.5, p.3742-3757, 2018. Available from: <https://pubmed.ncbi. nlm.nih.gov/29477517/>. Accessed: Feb. 02, 2020. doi: 10.3168/ jds.2017-13465. 
SIDIRA, M; et al. Evaluation of immobilized Lactobacillus plantarum 2035 on whey protein as adjunct probiotic culture in yoghurt production. LWT - Food Science and Technology, v.75, p.137-146, 2017. Available from: <https://www.infona. pl/resource/bwmeta1.element.elsevier-d0fcbbd6-af3d-3ea7abec-98df26c6de40\#>. Accessed: Mar. 02, 2020. doi: 10.1016/j. lwt.2016.08.026

SILVA, N. et al. Manual de métodos de análise microbiológica de alimentos e água. $5^{\mathrm{a}}$ ed., São Paulo: Blucher, 2017.

SOUSA, A. Z. B. de et al. Physical-chemical and microbiological aspects of the rennet cheese sold in the northeast states of Brazil. Food Safety, v.81, n.1, p.30-35, 2014. Available from: <https:// www.scielo.br/pdf/aib/v81n1/1808-1657-aib-81-01-00030.pdf.>. Accessed: Mar. 02, 2020

SUMARMONO, J. et al. Effect of storage conditions on the characteristics and composition of fresh oat cheese containing probiotics. Animal Production, v.21, n.1, p.56-63, 2020. Available from: $\quad<$ https://www.researchgate.net/publication/340688686>. Accessed: Mar. 02, 2020. doi: 10.20884/1.jap.2019.21.1.776.

TORRES, F. R. et al. Rapid consumer-based sensory characterization of requeijão cremoso, a spreadable processed cheese: performance of new statistical approaches to evaluate check-all-that-apply data. Journal of Dairy Science, v.100, n.8, p.6100-6110, 2017. Available from: <https:/www.sciencedirect. com/science/article/pii/S0022030217305404>. Accessed: Abr. 02, 2020. doi: 10.3168/jds.2016-12516.

TRIPATHI, M. K.; GIRI, S. K. Probiotic functional foods: survival of probiotics during processing and storage. Journal of Functional Foods, v.9, p.225-241, 2014. Available from: $<$ https:// pubag.nal.usda.gov/catalog/5441020>. Accessed: Mai. 02, 2020. doi: 10.1016/j.jff.2014.04.030

VANDENPLAS, Y. et al. Probiotics: an update. Jornal de Pediatria, v.91, n.1, p.6-21, 2015. Available from: <https://www.scielo.br/ scielo.php?script $=$ sci_arttext\&pid $=$ S0021-75572015000100006>. Accessed: Jun. 02, 2020. doi: 10.1016/j.jped.2014.08.005.

ZENDEBOODI, F.; et al. Probiotic: conceptualization from a new approach. Current Opinion on Food Science, v.32, p.103-123, 2020. Available from: <https://www.sciencedirect.com/science/ article/abs/pii/S221479932030028X\#>. Accessed: Set. 02, 2020. doi: $10.1016 /$ j.cofs.2020.03.009.

ZOUMPOPOULOU, G. et al. Dairy probiotics: beyond the role of promoting gut and immune health. International Dairy Journal, v.67, p.46-60, 2016. Available from: <https://www.researchgate. net/publication/309382312>. Accessed: Jul. 02, 2020. doi: 10.1016/j.idairyj.2016.09.010 